\title{
Clinical Case: About a Probable Case of Post-Transfusion Purpura in a Homozygous Sickle Cell
}

\section{Rakotoniaina Andriamiarimbola Irène ${ }^{1}$, Fenomama Jocia ${ }^{2}$, Fenomanana Maminirina Sonia ${ }^{3}$, Buscotin Eugenie ${ }^{4}$, Rasamindrakotroka Andry5, Rakoto Alson Olivat Aimé 6}

\author{
${ }^{1}$ Laboratory Department, University Hospital Mitsinjo Betanimena, Tuléar, Madagascar \\ ${ }^{2}$ Laboratory Department, University Hospital Tambohobe, Fianarantsoa, Madagascar \\ ${ }^{3}$ Maternity Department, University Hospital Tanambao, Tuléar, Madagascar \\ ${ }^{4}$ Pediatric Department, University Hospital Tanambao, Tuléar, Madagascar \\ ${ }^{5}$ Laboratory of Immunology Department, University Hospital HJRA, Antananarivo, Madagascar \\ ${ }^{6}$ Laboratory of Hematology Department, University Hospital HJRA, Antananarivo, Madagascar \\ Email: paps11380@yahoo.fr
}

How to cite this paper: Irène, R.A., Jocia, F., Sonia, F.M., Eugenie, B., Andry, R. and Aimé, R.A.O. (2017) Clinical Case: About a Probable Case of Post-Transfusion Purpura in a Homozygous Sickle Cell. Case Reports in Clinical Medicine, 6, 196-199.

https://doi.org/10.4236/crcm.2017.66018

Received: May 16, 2017

Accepted: June 27, 2017

Published: June 30, 2017

Copyright $\odot 2017$ by authors and Scientific Research Publishing Inc. This work is licensed under the Creative Commons Attribution International License (CC BY 4.0).

http://creativecommons.org/licenses/by/4.0/

\begin{abstract}
Alloimmunization to platelet antigens exposes to a serious immunological incident. We report a probable case of a post-transfusion purpura from homozygous sickle cell child alloimmunized against platelet antigen. We detail the challenges of alloantibody identification and transfusion management. These challenges are due to the lack of laboratory techniques for typing HLA and HPA system and the use of leukocyte-depleted (filtered) blood products.
\end{abstract}

\section{Keywords}

Post Transfusion Purpura, Thrombocytopenia, Sickle Cell Disease, Bumps

\section{Introduction}

Post-transfusion purpura is one of the rare immunologic reactions found in patients receiving multiple transfusions [1]. The use of non-leukocyte-depleted blood products increases the frequency of post transfusion event and exposes alloimmunization platelet [2]. This alloimmunization would be responsible for a later transfusion event. In our country, people with sickle cell disease form a part of the population that needs repeated transfusion. In Madagascar, the prevalence of sickle-cell disease is $9.2 \%$ [3]. Transfusion is an essential element in their treatment during a crisis. Because the leukocyte-depleted is not available, the whole-blood transfusion is always carried out. However, this practice exposes to 
transfusion event. We report a case of post-transfusion purpura in a homozygous sickle cell. We detail the challenges in the identification of the antibody incriminated as well as the short- and long-term challenges of the transfusion management of the child.

\section{Observation}

An 8-year-old girl with homozygous sickle cell disease was hospitalized for a sickle cell crisis. She has received 07 transfusion episodes since she was 26 months. The blood products used were always whole blood iso group iso rhesus. The blood group is O positive. At her last sickle cell crisis she presented hyperthermia, a mucosal cutaneous pallor. The biological results showed anemia ( $\mathrm{Hb}$ : $60 \mathrm{~g} / \mathrm{l})$, leukocyte rise, with a normal platelet rate, high $\mathrm{C}$ reactive (CRP $=24$ $\mathrm{mg}$ ). The search for plasmodium was negative. The child had antibiotic treatment and was transfused with a whole blood. The clinical condition of the child improved but 5 days after transfusion she presented two bumps in the scalp $(5 \times$ $2 \mathrm{~cm}$ ) (Figure 1). These two bumps appeared suddenly without any notion of trauma. We examined the child and other signs of bleeding were not found except two bumps. These bumps were soft, painless. We have redone the hemogram which showed a deep thrombocytopenia at $30 \mathrm{Giga} / \mathrm{l}$.

In view of this fact no immunoglobulin was available therefore corticosteroid was administered. The change was good because the bump has gradually decreased in volume and eventually disappeared. Since this event, due to lack of leukocyte-depleted blood supply, the child has not received any blood transfusions despite her anemia, but only preventive treatment such as antibiotics prophylaxis, folic acid, good hydratation. One week after leaving the hospital, follow-up did not find any abnormalities except his anemia.

\section{Comments}

This observation illustrates the post transfusion risk of multiple transfusions when using non-leukocyte-depleted blood products. The risk of immunological event is $3 \%$ [1]. In our case, it is likely a post-transfusion purpura. In front of this event, we are faced with several challenges. Among them, there is the diagnostic challenge because we did not have the laboratory technical to demonstrate the

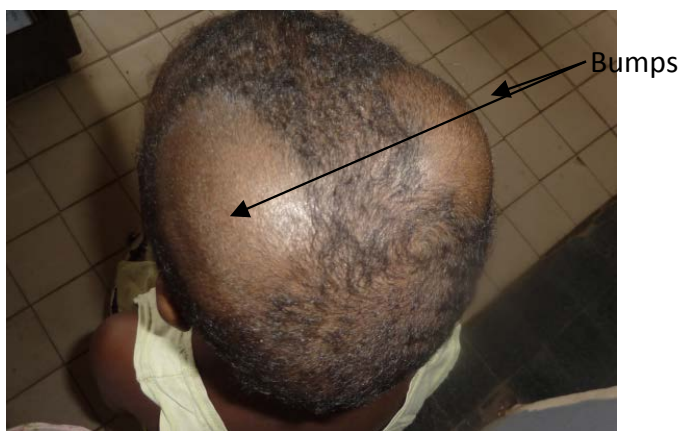

Figure 1. Two bumps 5 day after transfusion in a homozygous sickle cell. 
anti-platelet antibodies in question. Thus, diagnosis is based on medical history, clinical, and non-specific biology. It was a child who has received multiple whole blood transfusions. While whole blood transfusion induces frequent anti-HLA immunization due to non-leukocyte depleted. The risk of an immunological event is $36 \%$ in subjects previously stimulated [2]. In patients already sensitized the memory $\mathrm{T}$ lymphocytes can be rapidly activated by antigen presenting cells of the recipient presenting antigenic peptides derived from the incompatible HLA molecules of the transfused product. This activation of memory $\mathrm{T}$ lymphocytes results in the production of anti-HLA IgG alloantibodies [4]. Regarding the clinic, spontaneous hemorrhagic syndrome occurs on the scalp without any notion of trauma. The hemorrhagic syndrome appeared 5 days after the blood transfusion in a repeated transfused patient [5]. There are also other hemorrhagic signs such as petechiae, purpura, mucosal hemorrhagic encountered in other patients who have made a post transfusion purpura [6].

The non-specific biological argument is based on the number of platelets that are collapsed. Major thrombocytopenia was observed a few days after transfusion because the blood count before transfusion showed a normal platelet count. The immunological event due to HPA alloantibodies is responsible for major collapse of platelet count because it results in both destruction of recipient and donor platelets [2].

In the face of the medical history, the clinic and especially the collapse of the platelet rate we retained the diagnosis of post transfusion purpura. Even if the antibody against-HLA alloimmunization is more frequent than the antibody against-HPA [7], in our case the presence of platelet-specific antigens is not ruled out by this major thrombocytopenia, especially patients with anti-HLA alloimmunization more frequently develop anti-HPA antibodies [2].

Concerning challenge in the treatment, HPA and HLA typing of the child could not be conducted. As a result, we were unable to select compatible HPA or HLA platelet concentrates from typical donors. We didn't have any typing techniques, whether serological or molecular. Due to the unavailability of immunoglobulin treatment with corticosteroid was administered [8].

Blood transfusion, especially red blood cell concentrates (RBCs), is an essential part of sickle cell therapy. It has improved the morbidity and mortality of these patients, but like any other developing countries, we don't have leukocyte-depleted blood that will reduce adverse effects in this patient [9]. A new transfusion could therefore expose the child to severe complications if no blood from a typical donor is used [6]. All these difficulties put at stake the short-term and long-term prognosis of our patient.

\section{Conclusion}

This is the first reported case of post-transfusion purpura in a multitransfused patient. In this case, the likely diagnosis of a post-transfusion purpura has been retained in front of his medical history, hemorrhagic syndrome and major thrombocytopenia. Faced with the challenges of diagnosis and management, we 
are sometimes confronted with a situation of blocking transfusion. Due to lack of leukocyte-depleted blood products and phenotyping HLA HPA, the management of multi-transfused patients is a constraint for blood transfusion establishments.

\section{References}

[1] Aullen, J.-P., et al. (2010) Les effets indésirables receveurs inconnus de cinq régions françaises: Analyse, résultats, propositions. Transfusion Clinique et Biologique, 17, 20-27. https://doi.org/10.1016/j.tracli.2009.11.002

[2] Basire, A. and Picard, C. (2014) Stratégies d'exploration de l'allo-immunisation plaquettaire pour la prévention et la prise en charge des inefficacités transfusionnelles plaquettaires. Transfusion Clinique et Biologique, 21, 193-206. https://doi.org/10.1016/j.tracli.2014.08.140

[3] http://www.drepanocytose-madagascar.org/pdf/Bilan-moral-2011.pdf

[4] Semple, J.W., Speck, E.R., Milev, Y.P., Blanchette, V. and Freedman, J. (1995) Indirect Allorecognition of Platelets by $\mathrm{T}$ Helper Cells during Platelet Transfusions Correlates with Anti-Major Histocompatibility Complex Antibody and Cytotoxic T Lymphocyte Formation. Blood, 86, 805-812.

[5] Moncharmont, P. and Rigal, D. (2012) Prevalence of Platelet-Specific Antibodies in the Recipients of Platelet Units with Transfusion Adverse Event. Transfusion Clinique et Biologique, 19, 333-337. https://doi.org/10.1016/j.tracli.2012.06.003

[6] Kaplan, C. (2006) Le purpura post-transfusionnel. Hématologie, 12, 61-65.

[7] Pavenski, K., Freedman, J. and Semple, J.W. (2012) HLA Alloimmunization against Platelet Transfusions: Pathophysiology, Significance, Prevention and Management. Tissue Antigens, 79, 237-245. https://doi.org/10.1111/j.1399-0039.2012.01852.x

[8] McFarland, J.G. (2001) Post Transfusion Purpura. Transfusion Reactions. AABB Press, Bethesda, MD, 187-212.

[9] Yazer, M.H., Podlosky, L., Clarke, G. and Nahirniak, S.M. (2004) The Effect of Prestorage WBC Reduction on the Rates of Febrile Nonhemolytic Transfusion Reactions to Platelet Concentrates and RBC. Transfusion, 44, 10-15. https://doi.org/10.1046/j.0041-1132.2003.00518.x

Scientific Research Publishing

\section{Submit or recommend next manuscript to SCIRP and we will provide best service for you:}

Accepting pre-submission inquiries through Email, Facebook, LinkedIn, Twitter, etc. A wide selection of journals (inclusive of 9 subjects, more than 200 journals)

Providing 24-hour high-quality service

User-friendly online submission system

Fair and swift peer-review system

Efficient typesetting and proofreading procedure

Display of the result of downloads and visits, as well as the number of cited articles

Maximum dissemination of your research work

Submit your manuscript at: http://papersubmission.scirp.org/

Or contact crcm@scirp.org 